\title{
Metabolic Studies in Familial Partial Lipodystrophy of the Lower Trunk and Extremities
}

\author{
M. B. Davidson and R. T. Young \\ Dept. of Medicine, UCLA School of Medicine, Los Angeles, California, USA
}

Received: March 26, 1975, and in revised form: September 8, 1975

\begin{abstract}
Summary. A familial syndrome of partial lipodystrophy inherited as a dominant trait is reported. Subcutaneous fat loss was confined to the extremities and trunk. Diabetes mellitus, hyperlipidemia, hepatomegaly and renal disease were very prevalent in this family. Metabolic studies were performed on 3 members. In vivo tests suggested that the remaining fat tissue responded normally to stimulators and inhibitors of lipolysis. In vitro incubation of the dystrophic fat tissue of one patient suggested that the intracellular
\end{abstract}

pathways of lipid and glucose metabolism were normal. The pattern of subcutaneous loss of adipose tissue observed in this family may be due to sympathetic nervous system overactivity of certain non-contiguous dermatomes.

Key words: Lipodystrophy, lipoatrophy, partial lipodystrophy, adipose tissue, black adrenal adenoma.
Total lipodystrophy (lipoatrophic diabetes) was described by Lawrence in 1946 [1]. This condition [2, 3] is characterized by a complete loss of adipose tissue either in the neonatal period or later in life. It is commonly associated with hyperlipidemia, hepatomegaly, ketosis-resistant and insulin-resistant diabetes mellitus, increased basal metabolic rate with normal thyroid tests and early rapid growth. Urinary diabetogenic polypeptide [4] is present, although it can also be found in most diabetics with diabetic nephropathy and albuminuria [5]. Recently, excessive amounts of a lipid mobilizing substance were found in the urine of a patient with lipoatrophic diabetes [6]. Total lipodystrophy, sometimes seen in siblings, seems to follow an autosomal recessive genetic pattern $[2,3]$.

Weir Mitchell first described the more common syndrome of partial lipodystrophy in 1885 [7]. Classically this consists of loss of facial adipose tissue and loss to varying degrees in the remainder of the upper half of the body, with normal or even excessive amounts of fat in the lower half of the body $[2,3]$. This condition most commonly affects females, with onset before the age of 20 years. It is occasionally associated with metabolic features that accompany total lipodystrophy. However, urinary diabetogenic polypeptides have not been found. In addition, partial lipodystrophy is commonly associated with a variety of renal disorders $[2,3,8,9]$.

The relationships between total and partial lipodystrophy, the prevalence of diabetes mellitus and the genetic influence on these disorders have not been clarified [2, 3]. Recently, Köbberling et al. [10] have suggested the following classification. Total lipodystrophy exists in both the congenital and acquired forms. The congenital type can be autosomal recessively inherited. The acquired type develops in late childhood or early adulthood and its onset may follow an acute or chronic illness. It does not seem to be inherited. Both types of generalized lipodystrophy should be differentiated from partial lipodystrophy. Classically, the loss of fat in this condition has involved the trunk and face (cephalothoracic lipodystrophy). Females are more commonly affected than males and a familial occurrence has rarely been described. Diabetes mellitus ("lipoatrophic diabetes") may occur in any type of lipodystrophy, but not necessarily so.

Several cases of partial lipodystrophy involving the extremities only have recently been reported $[10,11$, $12,13,14]$. We describe here a family in which partial lipodystrophy affecting the lower half of the body and the upper extremities indicates a dominant pattern of inheritance. The results of in vivo studies, utilizing inhibitors and stimulators of lipolysis and in vitro incubations of the dystrophic fat, are also reported.

\section{Case Summaries}

P. G., a 34 year old married woman, was seen at UCLA because of a left renal mass. Ten months prior to admission she began complaining of headaches and was found to be hypertensive, $160 / 90 \mathrm{~mm} \mathrm{Hg}$. Intravenous pyelography revealed a left renal mass 
which was confirmed by a retrograde pyelogram. She was admitted for urological surgery.

Physical examination disclosed an unusual distribution of subcutaneous fat, with preservation on the face and upper trunk associated with loss over the buttocks and both upper and lower extremities. Other positive findings were moderate facial hair, a $7 \times 3 \mathrm{~cm}$ mass in the left upper quadrant and a nontender liver extending $8 \mathrm{~cm}$ below the right costal margin.

Normal laboratory tests included: Full blood count, electrolytes, bilirubin, creatinine, blood urea nitrogen, calcium, phosphorus, VDRL, prothombin time, alkaline phosphatase, total protein, amylase, testosterone and urinary 17-ketosteroids. An overnight dexamethasone suppression test was normal. Plasma cortisol and thyroxine were slightly elevated, probably secondary to conjugated estrogen therapy. Creatinine clearance was $109 \mathrm{ml} / \mathrm{min}$. Karyotype was $46 \mathrm{XX}$.

Abnormal laboratory tests included: Glucosuria with a diabetic glucose tolerance test (Table 1), fasting triglycerides $(812 \mathrm{mg} / 100 \mathrm{ml})$, cholesterol (300 $\mathrm{mg} / 100 \mathrm{ml}$ ) and slight elevations of SGOT, SGPT, $\mathrm{LDH}$ and uric acid. Lipoprotein electrophoresis was consistent with a type IV pattern.

At surgery a sample of subcutaneous fat from the left flank was removed for in vitro metabolic studies (see below). Liver enlargement was confirmed and a biopsy was taken. A muscle biopsy from the left abdominal rectus group was also obtained. A left renal cyst (approximately $14 \mathrm{~cm}$ in diameter) was found. Left nephrectomy and adrenalectomy were performed. Abundant pericapsular fat was noted around the kidney.

Pathological examination revealed: 1) a benign renal cyst; 2) a normal sized adrenal gland containing a cortical tumor $(0.3 \mathrm{~cm}$ in width) consistent with the diagnosis of black adenoma; 3 ) fatty infiltration of the liver; and 4) normal abdominal rectus muscle. After an uneventful recovery, the blood pressure fell to normal. She was lost to follow-up for $2 \frac{1}{2}$ years at which time she returned with polyuria, polydipsia, fatigue, weight loss, glucosuria, mild ketonuria and albuminuria ( $2.9 \mathrm{~g}$ protein per $24 \mathrm{hrs}$ ). Her diabetes mellitus is currently controlled with insulin injections.

O. R. is the 53 year old mother of P. G. She had been in good health most of her life except for a spinal fusion in 1967 for a probable herniated disc and a history of fractures of her coccyx, right forearm, a finger and her right ankle. She also noted the recent onset of mild headaches, tremor and loss of memory 4-5 hrs after eating. These symptoms were quickly relieved by food.

Physical examination was negative except for the similar abnormal distribution of subcutaneous fat
(Fig. 1A), bruits in the epigastric region and over both femoral arteries and a cast on the right ankle for a recent fracture of the lateral malleolus.

Normal laboratory tests included: Full blood count, urinalysis, calcium, phosphorus, bilirubin, SGOT, total proteins, albumin, alkaline phosphatase, uric acid and serum testosterone. Serum thyroxine, determined by a protein binding method employing column separation, was slightly elevated. Fasting triglyceride concentration was $168 \mathrm{mg} / 100 \mathrm{ml}$ (normal 50-175 $\mathrm{mg} / 100 \mathrm{ml}$ ) and cholesterol was $295 \mathrm{mg} / 100 \mathrm{ml}$. An overnight dexamethasone suppression test was normal. An oral glucose tolerance test was abnormal (Table 1). An intravenous pyelogram revealed abdominal aortic calcification, a left kidney with a straight axis, but no evidence of a renal mass, and diffuse bony demineralization. Carotid calcification and mild hypertrophic degenerative changes of the cervical spine were also present.

E. W. is the niece of O.R. and a first cousin of P. G. (Fig. 1B). She was seen at UCLA at the age of 32 for evaluation of partial lipodystrophy. At age 27 , diabetes mellitus was diagnosed during one of her pregnancies and she was treated briefly with insulin.

Past history revealed surgery for ovarian "tumors and cysts," two cesarean sections, an appendectomy and a total hysterectomy. She had intermittent hypertension, a peptic ulcer documented by an upper gastrointestinal series and a left renal mass (diagnosed by intravenous pyelography) for which she refuses surgery. A history of multiple fractures included 4 separate documented fractures of the wrist and fractures of the coccyx, large toe and various fingers.

Physical examination revealed the typical habitus (Fig. 1B) with preservation of subcutaneous fat on her face and upper trunk, and loss over the buttocks and both upper and lower extremities. Blood pressure was normal. A nontender liver extending $8 \mathrm{~cm}$ below the right costal margin and a mild decrease in vibratory sensation in the lower extremities were also present.

Normal laboratory examination included: Full blood count, creatinine, blood urea nitrogen, bilirubin, SGOT, alkaline phosphatase, total protein, albumin, LDH, electrolytes, calcium, phosphorus, uric acid, CPK, aldolase, testosterone, thyroxine, bleeding time, prothrombin time and urinary aldosterone, catecholamines, 17-KS, 17-KGS and pregnanetriol. An overnight dexamethasone suppression test was normal. Karyotype was 46XX. A chest film was normal. Serum triglycerides were $881 \mathrm{mg} / 100 \mathrm{ml}$ with a cholesterol of $220 \mathrm{mg} / 100 \mathrm{ml}$ and a type IV pattern on lipoprotein electrophoresis. Urinalysis showed positive tests for glucose and acetone. An oral glucose tolerance test was abnormal (Table 1). 
Table 1. Oral glucose tolerance test

\begin{tabular}{|c|c|c|c|c|c|c|c|c|c|}
\hline \multirow[b]{2}{*}{$\begin{array}{l}\text { Time } \\
\text { (hrs) }\end{array}$} & \multirow{2}{*}{$\begin{array}{l}\text { Subject P. G. } \\
\begin{array}{l}\text { Glucose } \\
(\mathrm{mg} / 100 \mathrm{ml})\end{array}\end{array}$} & \multicolumn{4}{|l|}{ Subject O. R. } & \multicolumn{4}{|l|}{ Subject E. W. } \\
\hline & & $\begin{array}{l}\text { Glucose } \\
(\mathrm{mg} / 100 \mathrm{ml})\end{array}$ & $\begin{array}{l}\text { IRI } \\
(\mu \mathrm{U} / \mathrm{ml})\end{array}$ & $\begin{array}{l}\text { FFA } \\
(\mu E q / L)\end{array}$ & $\begin{array}{l}\text { Glycerol } \\
(\mu \mathrm{M} / L)\end{array}$ & $\begin{array}{l}\text { Glucose } \\
(\mathrm{mg} / 100 \mathrm{ml})\end{array}$ & $\begin{array}{l}\text { IRI } \\
(\mu \mathrm{U} / \mathrm{ml})\end{array}$ & $\begin{array}{l}F F A \\
(u E q / L)\end{array}$ & $\begin{array}{l}\text { Glycerol } \\
(\mu \mathrm{M} / \mathrm{L})\end{array}$ \\
\hline $0^{a}$ & 150 & 94 & 20 & 925 & 77 & 117 & 55 & 1030 & 67 \\
\hline 0.5 & 198 & 190 & 78 & 769 & 61 & 216 & 175 & 833 & 72 \\
\hline 1 & 258 & 230 & 122 & 550 & 54 & 303 & 400 & 756 & 52 \\
\hline 2 & 348 & 197 & 175 & 438 & 41 & 290 & 570 & 494 & 45 \\
\hline 3 & 276 & 164 & 170 & 421 & 41 & 167 & 225 & 494 & 44 \\
\hline 4 & - & 103 & 42 & 421 & 37 & 96 & 105 & 473 & 41 \\
\hline 5 & - & 64 & 18 & 810 & 95 & - & $\ldots$ & - & - \\
\hline
\end{tabular}

${ }^{a} 100$ gms dextrose given by mouth after the initial sample
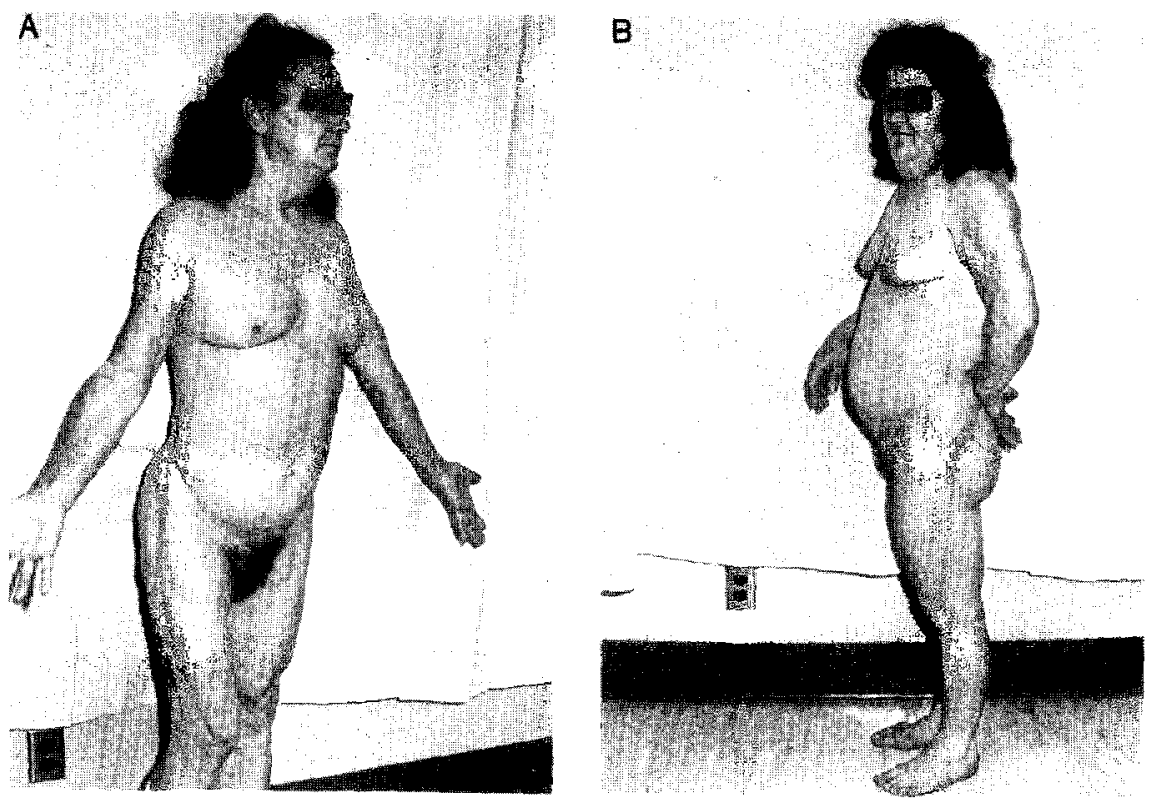

Fig. 1. Distribution of subcutaneous fat of O.R. (A) and E. W. (B). Note the presence of facial fat and absence of subcutaneous fat (denoted by prominence of venous patterns and muscle groups) over extremities and buttocks

\section{Materials and Methods}

\section{In Vivo Studies}

The nature and risks were explained to all patients and an informed consent was obtained. All studies were carried out after an overnight fast. Oral glucose, intravenous nicotinic acid, aminophylline and insulin were given in the amounts and times indicated in Tables 1,2 and 3. Ten ml blood samples were withdrawn at the appropriate times and placed in iced, heparinized tubes. After centrifugation, plasma glucose concentrations were measured by a glucose oxi- dase method (Beckman Glucose Analyzer) and the remaining plasma frozen for additional determinations of free fatty acids (FFA) [15], glycerol [16], immunoreactive insulin (IRI) [17] and growth hormone (GH) [18].

\section{In Vitro Studies}

Subcutaneous adipose tissue was removed from $P$. G. at surgery, immediately placed in saline and quickly brought to the laboratory. Approximately $100 \mathrm{mg}$ pieces were incubated in Krebs-Ringer bicarbonate buffer with $4 \%$ albumin (KRBA) for 2 hrs. 
Table 2. FFA $(\mu E q / L)$ responses to aminophylline infusion

\begin{tabular}{clll}
\hline $\begin{array}{l}\text { Time } \\
\text { (mins) }\end{array}$ & $\begin{array}{l}\text { Subject } \\
\text { P. G. }\end{array}$ & $\begin{array}{l}\text { Subject } \\
\text { O. R. }\end{array}$ & $\begin{array}{l}\text { Subject } \\
\text { E. W. }\end{array}$ \\
\hline 0 & 1101 & 753 & 1093 \\
10 & 1159 & 737 & 1101 \\
20 & 1133 & 680 & 1023 \\
$30^{\text {a }}$ & 1137 & 689 & 1021 \\
40 & 1168 & 760 & 1049 \\
50 & 1172 & 1001 & 1170 \\
60 & 1214 & 1168 & 1206 \\
75 & 1372 & 1285 & 1238 \\
90 & 1414 & 1198 & 1170 \\
105 & 1416 & - & 1031 \\
120 & 1412 & - & 993 \\
\hline
\end{tabular}

a $500 \mathrm{mg}$ of aminophylline infused over half hour period starting after $30 \mathrm{~min}$ sample

Table 3. FFA $(\mu E q / L)$ responses to intravenous nicotinic acid and insulin

\begin{tabular}{cccl}
\hline $\begin{array}{l}\text { Time } \\
\text { (mins) }\end{array}$ & $\begin{array}{l}\text { Subject } \\
\text { P. G. }\end{array}$ & $\begin{array}{l}\text { Subject } \\
\text { O. R. }\end{array}$ & $\begin{array}{l}\text { Subject } \\
\text { E. W. }\end{array}$ \\
\hline $0^{\mathrm{a}}$ & 712 & 991 & 1399 \\
15 & 680 & 833 & 1367 \\
30 & 530 & 590 & 1067 \\
45 & 543 & 582 & 1211 \\
60 & 750 & 645 & 1166 \\
90 & $1019^{\mathrm{b}}$ & 1496 & 1170 \\
105 & 894 & - & - \\
120 & 625 & 1439 & - \\
150 & 600 & - & - \\
180 & 617 & - & -
\end{tabular}

a $100 \mathrm{mg}$ nicotinic acid injected intravenously after the initial sample

${ }^{b} 0.1 \mathrm{U} / \mathrm{Kg}$ regular insulin injected after the $90 \mathrm{~min}$ sample in subject $P$. G. only

Glucose- ${ }^{14} \mathrm{C}$ incorporation into glycogen and $\mathrm{CO}_{2}$ was determined $[19,20]$. To measure glucose conversion into total lipids, tissue lipids were extracted into a chloroform methanol solution [21]. An aliquot was evaporated to dryness in a scintillation vial and counted. Measurement of the ${ }^{14} \mathrm{C}$ label in tissue fatty acids, glyceride-fatty acid and glyceride-glycerol was carried out by standard methods [22]. Lipolysis was measured in $3 \mathrm{ml}$ of KRBA alone and in the presence of epinephrine bitartrate $(0.1 \mu \mathrm{g} / \mathrm{ml})$ or theophylline $(0.1 \mathrm{mg} / \mathrm{ml})$. After $2 \mathrm{hrs}$ of incubation, two $1 \mathrm{ml}$ aliquots were removed for FFA determinations. The FFA content of the albumin preparation was measured and subtracted from the final FFA concentration of each flask. Each separate experimental condition in the glucose metabolic studies and the lipolysis experiments was carried out in triplicate. Adipose tissue cells were dispersed with collagenase and cell size was measured on 100 cells with an ocular micrometer in a microscope [23]. To ensure that intact fat cells were being measured instead of isolated fat droplets, the adipocytes were mixed with Nile blue before counting since this dye is taken up by intact cells only. Cell surface area and volume [24] were calculated from the distribution of cell diameters.

\section{Results}

\section{In Vivo Studies}

Oral glucose tolerance test data are shown in Table 1. As expected, all three patients had glucose intolerance. Glycerol, FFA and IRI were also measured in O. R. and E. W. The late insulin peak, often noted in ketosis-resistant diabetics, is evident. In addition, the insulin response to glucose is excessive, which can not be explained by obesity since these two patients were within $15 \%$ of their ideal body weight. Excessive insulin release to various stimuli in the lipodystrophies has been noted previously $[25,26]$. The decrease in FFA and glycerol concentrations probably reflects an inhibition of lipolysis by endogenous insulin secretion. Glycerol levels would not be expected to fall only if increased reesterification of fatty acids were occurring.

All 3 subjects responded to intravenous aminophylline with an increase in FFA (Table 2). They also manifested the expected fall of FFA after nicotinic acid and 2 subjects (P. G. and O. R.) showed the characteristic rebound over basal levels (Table 3 ). In addition, exogenous insulin lowered FFA concentration in P. G. (Table 3).

All 3 subjects had normal fasting GH concentrations which were suppressed after glucose and rose to $15 \mathrm{ng} / \mathrm{ml}$ after insulin in P. G. and to $16 \mathrm{ng} / \mathrm{ml} 5 \mathrm{hrs}$ after oral glucose in O. R. GH dynamics seemed normal in these subjects.

\section{In Vitro Studies}

Adipocytes prepared from subcutaneous fat removed at surgery from P. G. were extremely small compared to controls of similar weight (Table 4). Subcutaneous fat was removed at surgery from G. F. and $R$. W. and used as control tissue for the in vitro evaluation of lipolysis. Since P. G. had diabetes mellitus, G. $F$. was specifically selected for comparison since he also had mild ketosis-resistant diabetes mellitus. Control tissue for in vitro studies on carbohydrate metabolism was collected at surgery from 7 other 
Table 4. Adipocyte size

\begin{tabular}{lllll}
\hline & Age & \% IBW & $\begin{array}{l}\text { Cell } \\
\text { diameter } \\
(\mu)\end{array}$ & $\begin{array}{l}\text { Cell } \\
\text { diameter } \\
\text { volume } \\
(\mathrm{pl})\end{array}$ \\
\hline Subject P. G. & 34 & 121 & 1.7 & 10 \\
Control G. F. & 60 & 110 & 64.8 & 282 \\
Control R. W. & 63 & 119 & 71.4 & 316 \\
Lab Controls $(\mathrm{n}=7)$ & $21-59$ & $86-109$ & $63.7-90.5$ & $70-580$ \\
\hline
\end{tabular}

a Percent ideal body weight calculated from Documenta Geigy: Scientific Tables, 6th Ed., Geigy Pharmaceuticals (1962) p. 623

Table 5. FFA release under basal $(B)$ conditions and in the presence of epinephrine $(E)^{a}$ or theophylline $(T)^{b}$

\begin{tabular}{lrllllllll}
\hline & \multicolumn{3}{c}{$\mathrm{nEq} / 100 \mathrm{mg}$ tissue } & \multicolumn{2}{c}{$\mathrm{nEq} / 10^{6}$ cells } & \multicolumn{3}{c}{$\begin{array}{l}\text { Percent } \\
\text { Increase }\end{array}$} \\
\hline $\begin{array}{l}\text { Sub- } \\
\text { ject }\end{array}$ & B & E & T & B & E & T & E & T \\
\hline P. G. & 72 & 190 & 308 & 9 & 23 & 37 & 164 & 328 \\
G. F. & 125 & 163 & 744 & 406 & 529 & 2415 & 30 & 495 \\
R. W. & 71 & 153 & 355 & 258 & 556 & 1291 & 115 & 400
\end{tabular}

${ }^{\text {a }}$ Epinephrine bitartrate $(0.1 \mu \mathrm{g} / \mathrm{ml})$

b (Theophylline $)_{2}$ ethylene diamine $(0.1 \mathrm{mg} / \mathrm{ml})$

c Calculated as $100 \mathrm{X}$ difference between stimulated and basal divided by basal

Table 6. Recovery of glucose $-{ }^{14} \mathrm{C}$ in various products of glucose metabolism $\left(\mu \mathrm{g} / 10^{6}\right.$ cells $/ 2$ hrs $)$

\begin{tabular}{llrl}
\hline & Basal & Insulin $^{\mathrm{a}}$ & $\begin{array}{l}\text { Percent } \\
\text { increase }^{\mathrm{b}}\end{array}$ \\
\hline $\mathrm{CO}_{2}$ & & & \\
$\quad$ Subject P. G. & 0.24 & 0.29 & 21 \\
$\quad$ Controls (n=7) & 7.71 & 10.62 & 44 \\
$\begin{array}{l}\text { Glycogen } \\
\text { Subject P. G. }\end{array}$ & 0.01 & 0.03 & 200 \\
$\quad$ Controls (n=7) & 3.81 & 7.38 & 127 \\
$\begin{array}{c}\text { Total lipid } \\
\text { Subject P. G. }\end{array}$ & 0.15 & 0.26 & 73 \\
$\begin{array}{c}\text { Glyceride-Glycerol } \\
\text { Subject P. G. }\end{array}$ & 0.12 & 0.24 & 100 \\
\hline
\end{tabular}

${ }^{a}$ See text for insulin concentrations

${ }^{b}$ Calculated as $100 \mathrm{X}$ difference between responses in the presence and absence of insulin divided by the response under basal conditions

normal weight subjects without recent weight loss or known endocrine dysfunction.

In vitro studies on lipolysis are shown in Table 5. Basal release of FFA by tissue from P. G. is similar to control tissue when expressed per unit weight. Since basal lipolysis is proportional to cell size [27, 28, 29, 30 ], it was expected that adipocytes from P. G. would

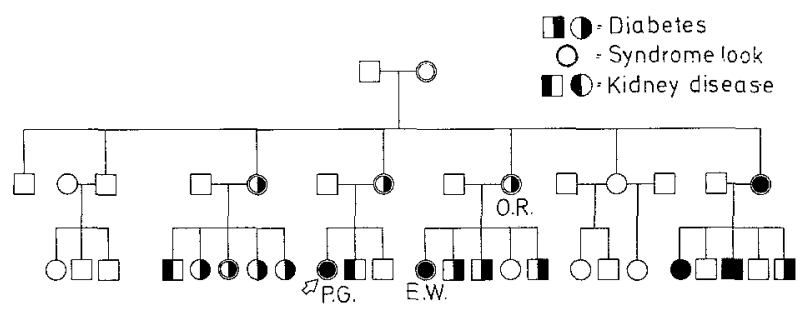

Fig. 2. Family pedigree. Syndrome look is defined as prominent venous patterns and muscle groups below the waist and over the upper extremities with obvious subcutaneous fat (double chin) over face

manifest low activity when expressed per cell. However, these small cells respond normally on a percentage basis to the lipolytic agents epinephrine and theophylline.

In vitro studies on glucose metabolism are shown in Table 6. Basal incorporation of glucose $-{ }^{14} \mathrm{C}$ into ${ }^{14} \mathrm{CO}_{2}$, glycogen and lipids was very much diminished. This was probably the result of the small size of the cell and was consistent with data on normal human adipocytes showing that glucose incorporation into total lipids [31], glyceride-glycerol $[30,31,32]$ and $\mathrm{CO}_{2}$ $[20,33]$ was proportional to cell size. The percent stimulation by insulin of glucose conversion to $\mathrm{CO}_{2}$ and glycogen was comparable in tissues from P. G. and from 7 control subjects. Tissue from P. G. was incubated with $10 \mathrm{mU} / \mathrm{ml}$ of insulin, whereas the maximal response to insulin concentrations of $1 \mathrm{mU} / \mathrm{ml}$ or less was used for the control subjects. However, previous experience in our laboratory with varying amounts of insulin (up to $100 \mathrm{mU} / \mathrm{ml}$ ) on tissue from the same subject revealed that maximal responses in vitro were usually attained at insulin concentrations of $1 \mathrm{mU} / \mathrm{ml}$ or below [20,33]. Furthermore, in earlier experiments on tissue from 6 normal weight control subjects, when results were expressed per $\mathrm{mg}$. DNA, $10 \mathrm{mU} / \mathrm{ml}$ of insulin increased glucose recovery in $\mathrm{CO}_{2}$ by $26 \%$ and in glycogen by $246 \%$ [19], values similar to the ones shown by P. G. Thus, dystrophic adipocytes seem to respond normally to insulin. Of particular note is the stimulation by insulin of glucose recovery in total lipids and glyceride-glycerol. Virtually no glucose- ${ }^{14} \mathrm{C}$ was incorporated into either tissue or glyceride fatty acids in vitro, a situation observed in normal adult adipose tissue $[19,22]$.

\section{Discussion}

Most patients with partial lipodystrophy lose subcutaneous fat on the face and trunk [2,3], a pattern named cephalothoracic or progressive lipodystrophy 
[10]. Familial occurrence in this form of partial lipodystrophy is rare, but has been reported in three families. In two of these, dominant inheritance would not seem to be present since the probands' uncle [34] and uncle and cousin [35] were the relatives involved. The proband's mother and grandmother were affected in the third family [36] which would be consistent with a dominant mode of inheritance.

The patients reported here had a different pattern of subcutaneous fat loss which involved the extremities and lower trunk. Some of the features that accompany total lipodystrophy were also present in these three subjects and include diabetes mellitus, with P. G. and E. W. manifesting hyperlipidemia and hepatomegaly. The black adenoma removed at surgery from P. G. is probably an incidental finding. There are less than 10 reported cases of this adenoma which is characterized by lipofuscin accumulation in adrenal cortical cells [37]. Its clinical significance is obscure.

The pedigree of this family is depicted in Fig. 2. In addition to the 3 designated patients, the brother and daughter of $\mathrm{E}$. W. were also examined briefly. The brother at age 28 has mild diabetes mellitus, hyperlipidemia and 3 documented myocardial infarctions. His distribution of subcutaneous fat is normal. The daughter at age 10 also has a normal distribution of subcutaneous fat. Both P. G. and E. W. became aware of their distinctive habitus as adolescents although neither could accurately date its onset.

Although the other family members live in the midwestern part of the United States and could not be examined directly, O. R. (who had been visiting her daughter in California when studied) returned home and furnished most of the information shown in Fig. 2. The labeling of a relative with diabetes mellitus is likely to be accurate and hence this endocrine disorder is probably present in other family members with normal fat distribution. However, the association of renal disease with this form of partial lipodystrophy must remain unproven. Glomerulonephritis with low $\mathrm{C}_{3}$ component of serum complement can accompany the cephalothoracic type of lipodystrophy $[8,9]$. There was no evidence for either in these patients since the urinary sediments were normal in all 3 subjects and $C_{3}$ components of serum complement were normal in $\mathrm{P}$. G. and E.W., the two in whom it was measured. P.G. had a renal cyst removed and subsequent development of albuminuria, which probably reflects diabetic glomerulosclerosis. E. W. has an abnormal intravenous pyelogram consistent with a renal mass, but refuses surgery. O. R. has an altered axis of one kidney but no evidence of a renal mass. Thus, the evidence is only suggestive that renal cysts may be associated with lipodystrophy of the lower trunk and extremities in this family.

Additionally, the possibility of osteoporosis in these patients can only be raised but not proven. E. W. and $\mathrm{O}$. R. give histories of multiple fractures, some of which may have occurred with minimal trauma. P. G. has also fractured her elbow and finger, but it is difficult to judge the extent of trauma involved. Bone $\mathrm{x}$-rays have not shown the typical changes of osteoporosis.

Previous reports of partial lipodystrophy of the trunk and extremities describe both familial $[10,13$, $14]$ and sporadic cases $[10,11,12]$. None of these has mentioned concomitant renal or bone disease. The familial cases show a dominant pattern of inheritance. By virtue of the relationship depicted in Fig. 2, the proposed mode of inheritance in this family is also postulated to be dominant. The pedigree is too small to ascertain if a sex-linked or sex-influenced dominance is involved.

FFA levels in these three patients appropriately decreased after endogenous or exogenous insulin and nicotinic acid and increased after an aminophylline infusion. These results are consistent with previous studies on patients with partial lipodystrophy whose FFA concentrations fell after nicotinic acid and insulin [25] and rose after noradrenaline [10]. Some patients with total lipodystrophy also manifested appropriate FFA responses to insulin $[6,36,38,39]$, nicotinic acid [40], catecholamines [40, 41, 42] and fasting [41] whereas others showed relatively fixed FFA concentrations after insulin [42, 43, 44], catecholamines [42, $43,44]$ and nicotinic acid [42]. These FFA changes indicate that the non-dystrophic adipocytes in patients with partial lipodystrophy and even the dystrophic fat cells in certain patients with "total" lipodystrophy can respond to various lipolytic and antilipolytic stimuli. Thus, the intrinsic abnormality in lipoatrophy is not a generalized alteration of intracellular lipid metabolism.

In vitro studies of the dystrophic adipocytes removed from P. G. at surgery support this view. Basal and stimulated lipolysis were comparable to control tissue when expressed per unit weight of tissue. Although activity per cell was much less, reflecting the diminished amount of stored triglycerides [27, 28, 29, $30]$, the percent increases after epinephrine and theophylline were similar to control tissues. Thus the mechanisms involved in activation of adenyl cyclase by epinephrine and inhibition of phosphodiesterase by theophylline are not impaired in the dystrophic fat cell. Recently, Boucher [26] has postulated that the sensitivity of the $\beta$-adrenergic receptor is increased in adipose tissue of the involved areas leading to disap- 
pearance of subcutaneous fat by enhanced lipolysis. These in vitro data showing a normal percent stimulation of lipolysis by epinephrine do not lend support to this hypothesis.

Lipid synthesis is reported to be depressed in dystrophic adipose tissue incubated in vitro [41]. However, this pathway is also proportional to fat cell size $[30,31,32]$ and the decreased incorporation of radioactive precursors into lipids probably reflects the remarkably small cell size of the affected adipocyte. The normal response of lipid synthesis to insulin in the present study suggests that depression of this metabolic pathway is due to cell size and not to an intrinsic intracellular metabolic abnormality. These in vitro data showing relatively normal stimulation of lipolysis by epinephrine and of triglyceride synthesis by insulin suggest that the dystrophic adipocyte is capable of synthesizing and breaking down lipids. The in vivo counterpart of this conclusion is the elevated turnover of FFA in total lipodystrophy [39, 45]. The normal insulin-mediated increases of glucose incorporation into lipids, $\mathrm{CO}_{2}$ and glycogen in vitro also argue against a primary role for adipose tissue in the pathogenesis of the chemical or overt diabetes mellitus associated with these syndromes.

Since these data do not point toward an intrinsic abnormality of the fat tissue, a change in the environment of the adipocyte may be responsible for the disappearance of subcutaneous fat. Steinberg and Gwinup [46] have emphasized the possible dermatome distribution of subcutaneous fat loss. The disappearance of subcutaneous fat tissue in our subjects also seemed to follow dermatomal distribution, although the dermatomes were not contiguous. Since denervation of adipose tissue will retard lipolysis [47] and lead to an accumulation of fat [48], Steinberg and Gwinup have postulated that regional overactivity of the sympathetic nervous system might explain the loss of subcutaneous fat [46]. Their hypothesis is supported by the demonstration that fat tissue transplanted to an atrophic site atrophies while dystrophic cells can reaccumulate fat if placed in a non-atrophic area [49]. On the other hand, there are at least two instances $[26,50]$ where normal fat survived when transplanted to an atrophic area. The failure of the tissue to be re-enervated normally could possibly explain these latter results although this is, of course, speculative. Since there is little convincing evidence of an intrinsic abnormality in the dystrophic adipocyte itself, we tend to favor the hypothesis of regional overactivity of the sympathetic nervous system, at least to explain the syndrome of partial lipidystrophy.
Acknowledgements. We gratefully acknowledge Robert G. Karjala for excellent technical assistance, Dr. Steven Cedarbaum for "genetic counselling," Dr. Eugene Barnett for performing the complement assays, Charlotte Smith for typing the manuscript and the cooperation of P. G., E. W. and O. R. for helping us learn more about partial lipodystrophy.

\section{References}

1. Lawrence, R. D.: Lipodystrophy and hepatomegaly with diabetes, lipaemia and other metabolic disturbances: A case throwing new light on the action of insulin. Lancet $1946 \mathrm{I}$, $724-741$ and $773-775$

2. Senior, B., Gellis, S. S.: The syndromes of total lipodystrophy and of partial lipodystrophy. Pediatrics 33, 593-612 (1964)

3. Podolsky, S.: Diabetes mellitus, Chap 28. In: Lipoatrophic diabetes and miscellaneous conditions related to diabetes mellitus (eds), A. Marble, P. White, R. F. Brandley, L. P. Krall, p. 722. Philadelphia: Lea \& Febiger 1971

4. Louis, L. H., Conn, J. W., Minick, M. C.: Lipoatrophic diabetes: Isolation and characterization of an insulin antagonist from urine. Metabolism 12, 867-886 (1963)

5. Louis, L. H., Conn, J. W., Minick, M. C.: A diabetogenic polypeptide from bovine adenohypophysis similar to that excreted in lipoatrophic diabetes. Metabolism 15, 308-324 (1966)

6. Taton, J., Malczewski, B., Wisniewska, A.: Studies on the pathogenesis of lipoatrophic diabetes: A case of congenital resistant diabetes mellitus and hepatosplenomegaly. Diabetologia 8, 319-325 (1972)

7. Mitchell, S. W.: Singular case of absence of adipose matter in upper half of the body. Amer. J. med. Sci. 90, 105-109 (1885)

8. Peters, D. K., Charlesworth, J. A., Sissons, J. G. P., Williams, D. G., Boulton-Jones, J. M., Evans, D. J., Kourilsky, O., MorelMaroger, L.: Mesangiocapillary nephritis, partial lipodystrophy and hypocomplementaemia. Lancet 1973 II, 535-538

9. Thompson, R. A., White, R. H. R.: Partial lipodystrophy and hypocomplementaemic nephritis. Lancet 1973 II, 679

10. Köbberling, J., Willms, B., Kattermann, R., Creutzfeldt, W.: Lipodystrophy of the extremities. A dominantly inherited syndrome associated with lipatrophic diabetes. Humangenetik 29, 111-120 (1975)

11. Bigler, J. A.: Loss of subcutaneous fat of the lower extremities (lipodystrophy). J. Amer. med. Ass. 112, 627-628 (1939)

12. Tzagournis, M., George, J., Herrold, J.: Increased growth hormone in partial and total lipoatrophy. Diabetes 22, 388-396 (1973)

13. Dunnigan, M. G., Cochrane, M. A., Kelly, A., Scott, J. W.: Familial lipoatrophic diabetes with dominant transmission. Quart. J. Med. 43, 33-48 (1974)

14. Ozer, F. L., Lichtenstein, J. R., Kwiterovich, P. O., McKusick, V. A.: A "new" genetic variety of "lipodystrophy." Clin. Res. 21, 533 (1973)

15. Davidson, M. B., Bernstein, J. M.: The effect of nicotinic acid on growth hormone induced lipolysis and glucose intolerance. J. Lab. clin. Med. 81, 568-576 (1973)

16. Davidson, M. B., Karjala, R.: Simplified fluorometric method for the determination of plasma glycerol. J. Lipid Res. 11, 609-612 (1970)

17. Soeldner, J. S., Slone, D.: Critical variables in the radioimmunoassay of serum insulin using the double antibody technic. Diabetes 14, 771-779 (1965)

18. Boden, G., Soeldner, J. S.: A sensitive double antibody radioimmunoassay for human growth hormone (HGH): Levels 
of serum $\mathrm{HGH}$ following rapid tolbutamide infusion. Diabetologia 3, 413-421 (1967)

19. Davidson, M. B.: Effect of obesity on insulin sensitivity of human adipose tissue. Diabetes 21, 6-12 (1972)

20. Davidson, M. B.: Glucose metabolism in human adipose tissue of obese and normal weight subjects. Israel J. med. Sci. 8, 826-829 (1972)

21. Folch, J., Lees, M., Sloane-Stanley, G. H.: A simple method for the isolation and purification of total lipids from animal tissues. J. biol. Chem. 226, 497-509 (1957)

22. Kahlenberg, A., Rubinger, J., Kalant, N.: Differences in the glucose metabolism and insulin responsiveness of rat and human adipose tissue. Canad. J. Biochem. 44, 645-648 (1966)

23. Bray, G. A.: Measurement of subcutaneous fat cells from obese patients. Ann. intern. Med. 73, 565-569 (1970)

24. Goldrick, R. B.: Morphological changes in the adipocyte during fat deposition and mobilization. Amer. J. Physiol. 212, 777-782 (1967)

25. Piscatelli, R. L., Vieweg, R. V. W., Havel, R. J.: Partial lipodystrophy. Metabolic studies in three patients. Ann. intern. Med. 73, 963-970 (1970)

26. Boucher, B. J., Cohen, R. D., Frankel, R. J., Mason, A. S., Broadley, G.: Partial and total lipodystrophy: Changes in circulating sugar, free fatty acids, insulin and growth hormone following the administration of glucose and of insulin. Clin. Endocr. 2, 111-126 (1973)

27. Goldrick, R. B., McLoughlin, G. M.: Lipolysis and lipogenesis from glucose in human fat cells of different sizes. J. clin. Invest. 49, 1213-1223 (1970)

28. Zinder, O., Shapiro, B.: Effect of cell size on epinephrine- and ACTH-induced fatty acid release from isolated fat cells. J. Lipid Res. 12, 91-95 (1971)

29. Gries, F. A., Berger, M., Neumann, M., Preiss, H., Leibermeister, H., Hesse-Wortmann, C., Jahnke, K.: Effects of norepinephrine, theophylline and dibutyryl cyclic AMP on in vitro lipolysis of human adipose tissue in obesity. Diabetologia 8, 75-83 (1972)

30. Björntorp, P., Sjostrom, L.: The composition and metabolism in vitro of adipose tissue fat cells of different sizes. Europ. J. clin. Invest. 2, 78-84 (1972)

31. Smith, U.: Effect of cell size on lipid synthesis by human adipose tissue in vitro. J. Lipid Res. 12, 65-70 (1971)

32. Björntorp, P., Karlsson, M.: Triglyceride synthesis in human subcutaneous adipose tissue cells of different size. Europ. J. clin. Invest. 1, 112-117 (1970)

33. Davidson, M. B.: Insulin sensitivity of the large human adipocyte in vitro. Diabetes (in press Dec. 1975)

34. Igersheimer, W. W.: Progressive lipodystrophy: Etiologic aspects and report of a case. Amer. J. Dis. Child. 75, 206-213 (1948)
35. Taylor, W. B., Honeycutt, W. M.: Progressive lipodystrophy and lipoatrophic diabetes. Arch. Derm. 84, 31-36 (1961)

36. Barraquer Ferre, L.: Pathogenesis of progressive cephalothoracic lipodystrophy. J. nerv. ment. Dis. 109, 113-121 (1949)

37. Garret, R., Ames, R. P.: Black-pigmented adenoma of the adrenal gland. Arch. Path. 95, 349-353 (1973)

38. Samaan, N. A., Craig, J. W.: Serum insulin and growth hormone in lipoatrophic diabetes. Metabolism 18, 460-468 (1969)

39. Boucher, B. J., Cohen, R. D., France, W. M., Mason, A. S.: Plasma free fatty acid turnover in total lipodystrophy. Clin. Endocr. 4, 83-88 (1975)

40. Brunzell, J. D., Porte, D., Jr., Bierman, E. L.: On the mechanism of lipoatrophy in congenital lipodystrophy Clin. Res. 17, $122(1969)$

41. Berg, S. W., Jersild, R. A., Powell, R. C.: Total lipodystrophy: Studies of lipid synthesis and release. J. Lab. clin. Med. 76, 1005-1006 (1970)

42. Havel, R. J., Basso, L. V., Kane, J. P.: Mobilization and storage of fat in congenital and late-onset forms of "total" lipodystrophy. J. clin. Invest. 46, 1068 (1967)

43. Senior, B., Loridan, L.: Fat cell function and insulin in a patient with generalized lipodystrophy. J. Pediat. 74, 972-975 (1969)

44. Kikkawa, R., Hoshi, M., Shigeta, Y., Izumi, K.: Lack of ketosis in lipoatrophic diabetes. Diabetes 21, 827-831 (1972)

45. Eaton, R. P., Berman, M., Steinberg, D.: Kinetic studies of plasma free fatty acid and triglyceride metabolism in man. $\mathbf{J}$. clin. Invest. 48, 1560-1579 (1970)

46. Steinberg, T., Gwinup, G.: Lipodystrophy. A variant of lipoatrophic diabetes. Diabetes 16, 715-721 (1967)

47. Beznak, A. B. L., Hasch, Z.: The effect of sympathectomy on the fatty deposits in connective tissue. Quart. J. exp. Physiol. 27, 1-15 (1937)

48. Sidman, R. L., Fawcett, D. W.: The effect of peripheral nerve section on some metabolic responses of brown adipose tissue in mice. Anat. Rec. 118, 487-507 (1954)

49. Langhof, H., Zabel, R.: On lipodystrophia progressiva. Followup study of the case published by a A. Simmons in 1911 for the first time in German literature. Arch. Derm. Forsch. 210, 313-321 (1960)

50. Strandberg, J.: Fall von Hauttransplantation mit eigenartigem Resultat. Derm. Z. 12, 556-558 (1915)

M. B. Davidson, M. D.

Dept. of Medicine

UCLA School of Medicine

Los Angeles, California 90024

USA 